\title{
KOMBINASI MOBILIZATION WITH MOVEMENT DAN HOLD RELAX EXERCISE LEBIH BAIK DIBANDINGKAN KOMBINASI MOBILIZATION WITH MOVEMENT DAN ACTIVE RESISTANCE EXERCISE DALAM MENURUNKAN DISABILITAS PADA KASUS FROZEN SHOULDER IDIOPATIK DI DENPASAR
}

\author{
AA Lanang Dananjaya Putra Dewa WA ${ }^{1}$. Ketut Tirtayasa ${ }^{2}$. Sugijanto ${ }^{3}$. Dewa Putu Gde \\ Purwa Samatra $^{4}$ I Dewa Ayu Inten Dwi Primayanti ${ }^{5}$. I Made Muliarta ${ }^{6}$ \\ ${ }^{1}$ Program Magister Fisiologi Keolahragaan, Fakultas Kedokteran, Universitas Udayana, Denpasar \\ ${ }^{256}$ Departemen Ilmu Faal, Fakultas Kedokteran, Universitas Udayana, Denpasar \\ ${ }^{4}$ Departemen Neurologi, Fakultas Kedokteran, Universitas Udayana, Denpasar \\ ${ }^{3}$ Fakultas Fisioterapi, Universitas Esa Unggul, Jakarta \\ e-mail : Lanangdanan@gmail.com
}

\begin{abstract}
ABSTRAK
Frozen shoulder idiopatik adalah gangguan pada sendi glenohumeral bahu yang mengalami peradangan sehingga menyebabkan nyeri kronis, membatasi gerakan sendi bahu dalam melakukan aktivitas fungsional. Beberapa metode yang dapat menurunkan gejala yang ditimbulkan diantaranya mobilization with movement (MWM), hold relax exercise (HRE) dan active resistance exercise (ARE) dengan mengurangi rasa nyeri dan disabilitas pada sendi bahu serta meningkatkan kekuatan otot pada area bahu. Penelitian ini bertujuan untuk membuktikan kombinasi $M W M$ dan $H R E$ lebih baik daripada kombinasi $M W M$ dan ARE dalam menurunkan disabilitas bahu pada pasien frozen shoulder idiopatik. Penelitian menggunakan metode eksperimental dengan pre test and post test two group design. Pelaksanaan di klinik Fisioterapi Denpasar pada bulan Januari sampai Februari 2020. Sampel berjumlah 18 orang terdiri dari 11 orang perempuan dan 7 orang laki-laki yang dibagi secara acak dalam 2 Kelompok perlakuan. Kelompok I diberikan kombinasi $M W M$ dan $H R E$ dan Kelompok II diberikan kombinasi $M W M$ dan $A R E$. Alat ukur yang digunakan dalam penelitian ini adalah SPADI. Hasil penelitian yaitu kombinasi $M W M$ dan $H R E$ dapat menurunkan disabilitas pada frozen shoulder idiopatik dengan nilai signifikansi $\mathrm{p}<0,05$ dengan nilai 74,18 menjadi 50,16, kombinasi $M W M$ dan ARE dapat menurunkan disabilitas pada frozen shoulder idiopatik dengan nilai signifikansi $\mathrm{p}<0,05$ dengan nilai 72,61 menjadi 57,86. Simpulan dari penelitian ini adalah kombinasi $M W M$ dan $H R E$ lebih baik daripada kombinasi $M W M$ dan ARE dalam menurunkan disabilitas bahu pada kasus frozen shoulder idiopatik dengan nilai signifikansi $\mathrm{p}<0,05$.
\end{abstract}

Kata kunci: frozen shoulder, mobilization with movement, hold relax exercise dan active resistance exercise.

\author{
THE COMBINATION OF MOBILIZATION WITH MOVEMENT AND \\ HOLD RELAX EXERCISE IS BETTER THAN COMBINATION OF \\ MOBILIZATION WITH MOVEMENT AND ACTIVE RESISTANCE \\ EXERCISE IN REDUCING DISABILITY IN THE FROZEN SHOULDER \\ IDIOPATIC CASE IN DENPASAR
}




\section{ABSTRACT}

Idiopathic frozen shoulder is a disorder in the connective tissue that surrounds the glenohumeral shoulder joint, causing inflammation to stiffness which will limit movement and cause chronic pain that affects the ability of the shoulder joint to perform daily functional activities. Some methods, such as mobilization with movement training, hold relax exercise and active resistance exercise, can reduce symptoms such as pain and disability in the shoulder joint and increase muscle strength in the shoulder area. This study aims to prove that the combination of mobilization with movement and hold relax exercise is better than the combination of mobilization with movement and active resistance exercise in reducing shoulder disability in idiopathic frozen shoulder patients. This study uses an experimental method with pre-test and post-test two group design. This research was conducted at the Physiotherapy Clinic in Denpasar from January to February 2020. The study sample consisted of 18 people consisting of 11 women and 7 men who were randomly divided into 2 treatment groups. The first treatment group was given a combination of mobilization with movement and hold relax exercise and the second treatment group was given a combination of mobilization with movement and active resistance exercise. The measuring instrument used in this study was SPADI. The results in this study are the combination of mobilization with movement and hold relax exercise can reduce disability in idiopathic frozen shoulder with a significance value of $\mathrm{p}<0.05$ with a value of 74.18 to 50.16, a combination of mobilization with movement and active resistance exercise can reduce disability in idiopathic frozen shoulder with a significance value of $\mathrm{p}<0.05$ with a value of 72.61 to 57.86. The conclusion of this study is that the combination of mobilization with movement and hold relax exercise is better than mobilization with movement and active resistance exercise in reducing shoulder disability in idiopathic frozen shoulder cases with a significance value of $\mathrm{p}<0.05$.

Keyword: frozen shoulder, mobilization with movement, hold relax exercise and active resistance exercise

\section{PENDAHULUAN}

Gangguan atau keluhan nyeri bahu yang diakibatkan oleh pekerjaan akan menurunkan produktivitas. Selain itu, nyeri bahu sering dikaitkan dengan gangguan kemampuan untuk tidur, sehingga mempengaruhi suasana hati, konsentrasi dan penurunan yang cukup besar dari fungsi fisik, fungsi sosial, fungsi peran emosional. Gerakan pada bahu tentunya akan mempengaruhi pergerakan pada tangan, maka mobilitas bahu berpengaruh terhadap kinerja atau aktivitas sehari-hari (misalnya berpakaian, kebersihan pribadi, makan dan bekerja). Gangguan yang cukup mengganggu akibat keluhan pada bahu di antaranya adalah tidak mampu menyisir rambut, kesulitan dalam berpakaian, kesulitan memakai breastholder $(\mathrm{BH})$ bagi wanita, mengambil dan memasukkan dompet di saku belakang, mengangkat tangan ke atas dan gerakangerakan lainnya yang melibatkan sendi bahu ${ }^{1}$.
Nyeri pada bahu dalam jangka waktu yang lama akan menimbulkan keterbatasan dalam menggerakan bahu sebagaimana normalnya, keluhan ini sering disebut dengan frozen shoulder ${ }^{2}$. Frozen shoulder adalah kondisi etiologi yang ditandai dengan adanya keterbatasan yang signifikan dari gerak aktif dan pasif bahu yang terjadi karena kerusakan pada jaringan dalam ${ }^{3}$. Selain itu frozen shoulder dideskripsikan sebagai kondisi bahu dengan ciri - ciri rasa nyeri dan keterbatasan range of motion (ROM) pada gerakan aktif dan gerakan pasif yang akan mengganggu kegiatan sehari - hari ${ }^{4}$. Frozen shoulder terjadi akibat kapsul sendi yang mengelilingi sendi area bahu menjadi mengkerut dan membentuk jaringan parut, kondisi ini disebut capsulitis adeshiva bahu5.

Banyak upaya penanganan yang dilakukan untuk frozen shoulder seperti pemberian obat oral, injeksi kortikosteroid, latihan, mobilisasi sendi, distensi, akupuntur, 
manipulasi dan tindakan operasi ${ }^{6}$. Secara umum metode teknik manual yang biasanya digunakan fisioterapis dalam upaya untuk mengatasi kekakuan sendi bahu seperti traksi translasi, passive exercise, hold relax exercise, active resistance exercise, contract relax exercise, mobilization with movement dan masih banyak metode lainnya ${ }^{7}$.

Hold relax exercise adalah suatu terapi latihan dimana otot atau grup otot antagonis yang mengalami pemendekan akibat kekakuan dikontraksikan secara isometrik dengan optimal dan kemudian diikuti dengan rileksasi otot dengan tujuan perbaikan rileksasi pola antagonis dan perbaikan dari mobilisasi sendi. Tujuan teknik ini untuk memberikan peregangan pada otot-otot bahu sehingga membantu perbaikan pada gangguan body structure impairment yang terjadi seperti kontraktur dan spasme pada otot-otot bahu.

Active resistance exercise merupakan bagian dari active exercise, saat melakukan gerakan akan terjadi kontraksi otot secara statik maupun dinamik dengan diberikan tahanan dari luar, dengan tujuan meningkatkan kekuatan otot dan meningkatkan daya tahan otot. Tahanan dari luar bisa manual atau mekanik. Tahanan manual adalah tahanan yang kekuatannya berasal dari terapis dengan besarnya tahanan disesuaikan dengan kemampuan pasien dan besarnya beban tahanan yang diberikan tidak dapat diukur secara kuantitatif ${ }^{8}$.

Mobilization with movement (MWM) merupakan suatu teknik mobilisasi yang dikembangkan oleh Mulligan pada tahun 1993. Teknik ini menggabungkan aplikasi berkelanjutan teknik manual gliding untuk memaksa koreksi posisi sendi yang mengalami kesalahan posisi bersamaan dengan gliding tersebut kemudian diikuti dengan gerak sendi fisiologis (osteokinematic), baik secara aktif dilakukan oleh subjek atau pasif dilakukan oleh terapis ${ }^{9}$.

\section{METODE PENELITIAN}

Penelitian dilakukan di tempat praktek fisioterapi di wilayah Denpasar, pada bulan
Januari hingga Februari 2020. Penelitian bersifat eksperimental dengan rancangan pretest and post test two group design. Alat ukur yang digunakan untuk mengukur disabilitas bahu adalah SPADI yang terdiri dari 13 item pertanyaan.

\section{A. Sampel dan Populasi}

Teknik penarikan sampel menggunakan teknik purpossive sampling dengan menggunakan pemeriksaan fisioterapi dan sesuai dengan kriteria yang telah ditetapkan peneliti. Populasi adalah seluruh penderita frozen shoulder idiopatik yang datang ke tempat praktek fisioterapi di Denpasar pada bulan November sampai Desember 2019. Sampel yang digunakan berjumlah 18 orang yang kemudian dibagi menjadi 2 Kelompok perlakuan. Pada Kelompok I diberikan kombinasi mobilization with movement (MWM) dan hold relax exercise (HRE) dan Kelompok II diberikan kombinasi mobilization with movement dan active resistance exercise (ARE).

\section{B. Pengumpulan Data Penelitian}

Permintaan persetujuan kepada sampel dengan penjelasan secara lisan serta tulisan dengan inform consent mengenai maksud dan tujuan penelitian dan hak yang diperoleh oleh sampel. Selanjutnya melaksanakan tes pemeriksaan awal fisioterapi untuk mengetahui data umum dan disabilitas bahu pada sampel dengan alat ukur Shoulder Pain and Disability Indeks (SPADI). Kemudian diberikan penerapan kombinasi MWM + HRE pada Kelompok I dan MWM + ARE pada Kelompok II selama 6 minggu perlakuan, setiap hari Selasa, Kamis dan Sabtu oleh peneliti yang didampingi oleh tenaga fisioterapis yang berkompeten.

Teknik MWM dilakukan selama 18 kali terapi, 3 set dan 10 kali repetisi per set. Dilakukan ke arah fleksi, ekstensi, abduksi, aduksi, eksorotasi dan endorotasi pada bahu., setiap selesai melakukan 1 set subjek istirahat selama 1 menit. Manual terapi MWM ini diberikan pada Kelompok I dan Kelompok II.

HRE ini merupakan kombinasi pada Kelompok I dan dilakukan setelah teknik MWM selesai diterapkan pada Kelompok I. 
Dilakukan selama 18 kali terapi, repetisi 10 kali dan diulangi sebanyak 3 set, dilakukan secara perlahan tanpa menimbulkan rasa sakit, dilakukan dengan menggunakan 2 arah pola gerakan yaitu (1) pola fleksi, abduksi, eksorotasi dan (2) pola ekstensi, adduksi dan endorotasi pada bahu. Saat subjek berusaha menggerakan bahunya sesuai arah yang ditentukan kemudian diberikan tahanan maksimal oleh fisioterapis sampai tidak terjadi gerakan selama 10 detik kemudian digerakkan ke arah agonis secara rileks selama 5 detik kemudian diminta untuk melawan tahanan lagi selama 10 detik. Setiap set diberikan istirahat selama 30 detik.

ARE ini merupakan kombinasi pada Kelompok II dan dilakukan setelah teknik MWM selesai diterapkan pada Kelompok II. Dilakukan selama 18 kali terapi, repetisi 10 kali dan diulangi sebanyak 3 set setiap gerakannya, dilakukan secara perlahan tanpa menimbulkan rasa sakit, dilakukan menggunakan tahanan dari resistance band kearah elevasi, protaksi, retraksi, fleksi, ekstensi, abduksi, aduksi, eksorotasi dan endorotasi pada bahu. Kemudian subjek berusaha menggerakan bahunya sesuai arah yang ditentukan oleh fisioterapis secara bertahap. Setiap perpindahan gerakan diberikan istirahat 10 detik.

\section{Analisis Data}

\section{Uji Normalitas Data}

Uji normalitas pada penelitian ini dilakukan dengan shapiro-wilk test untuk mengetahui sebaran data berdistribusi normal atau tidak. Hasil analisis data penelitian ini berdistribusi normal karena nilai $\mathrm{p}>0,05$.

\section{Uji Homogenitas}

Uji homogenitas pada penelitian ini menggunakan Levene test. Pengujian ini dilakukan untuk mengetahui sebaran data bersifat homogen atau tidak. Hasil analisis data penelitian ini bersifat homogen karena $\mathrm{p}$ $>0,05$.

\section{Uji Hipotesis}

Uji yang digunakan untuk hipotesis 1 dan 2 menggunakan uji Paired t-test menganalisis efek kombinasi MWM dan HRE dengan MWM dan ARE dalam menurunkan disabilitas pada kasus frozen shoulder idiopatik untuk menguji kemaknaan data sebelum dan sesudah perlakuan Kelompok I dan Kelompok II. Uji hipotesis 3 menggunakan Independent t-test untuk mengetahui perbandingan kombinasi MWM dan HRE dengan MWM dan ARE dalam menurunkan disabilitas pada kasus frozen shoulder idiopatik untuk menguji kemaknaan selisih pada ke dua Kelompok.

\section{HASIL PENELITIAN}

\section{A. Deskripsi Subjek Penelitian}

Tabel 1. Data Karakteristik Subjek Penelitian

\begin{tabular}{|c|c|c|c|}
\hline $\begin{array}{c}\text { Karakterist } \\
\text { Subjek }\end{array}$ & $\begin{array}{c}\text { Kelompok I } \pm \\
\text { SD }\end{array}$ & $\begin{array}{l}\text { Kelompok II } \\
\quad \pm \text { SD }\end{array}$ & $\begin{array}{c}\text { Seli } \\
\text { sih }\end{array}$ \\
\hline Umur (th & $53,22 \pm 3,93$ & $52,33 \pm 3,74$ & 0,89 \\
\hline \multirow{2}{*}{ Gender } & $33,33 \pm 0,50$ & $44,44 \pm 0,50$ & \\
\hline & $66,67 \pm 0,50$ & $55,56 \pm 0,50$ & \\
\hline IMT & $22,23 \pm 2,16$ & $23,87 \pm 1,05$ & 1,64 \\
\hline
\end{tabular}

KAUPK2

(Kuesioner

Alat Ukur

Perasaan

$34,56 \pm 6,71 \quad 37,11 \pm 6,43$

2,55

Kelelahan

Kerja)

Tabel 2. Data Pekerjaan Subjek Penelitian

\begin{tabular}{cccc}
\hline Pekerjaan & $\begin{array}{c}\text { Kelompok } \\
\text { I }(\%)\end{array}$ & $\begin{array}{c}\text { Kelompok } \\
\text { II }(\%)\end{array}$ & $\begin{array}{c}\text { Jumlah ke } \\
\text { dua } \\
\text { Kelompok } \\
(\%)\end{array}$ \\
\hline $\begin{array}{c}\text { Ibu } \\
\text { Rumah } \\
\text { Tangga } \\
\text { PNS }\end{array}$ & $4 ;(44,44)$ & $3 ;(33,33)$ & $7 ;(38,88)$ \\
$\begin{array}{c}\text { Wiraswas } \\
\text { ta }\end{array}$ & $2 ;(22,22)$ & $2 ;(22,22)$ & $4 ;(22,22)$ \\
$\begin{array}{c}\text { Pensiuna } \\
\text { n }\end{array}$ & $2 ;(22,22)$ & $1 ;(11,11)$ & $3 ;(16,66)$ \\
\hline
\end{tabular}

Berdasarkan Tabel 1 dalam kategori usia menunjukkan bahwa karakteristik sampel pada Kelompok I dan Kelompok II memiliki rentang rerata usia yang serupa yaitu diantara 52 tahun dan 53 tahun. Dari segi gender persentase perempuan lebih tinggi yaitu $61 \%$ (11 orang perempuan) dan persentase laki- 
laki yaitu 39\% (7 orang laki-laki). Dari segi IMT ke dua Kelompok berada dalam kategori IMT normal. Berdasarkan Kuesioner alat ukur perasaan kelelahan kerja (KAUPK2) diketahui ke dua Kelompok masuk dalam kategori sangat lelah.

Berdasarkan Tabel 2 yaitu kategori pekerjaan diketahui bahwa sampel yang bekerja sebagai ibu rumah tangga mempunyai persentase tertinggi dengan nilai 38,88\% mengalami frozen shoulder idiopatik.

\section{B. Uji Normalitas dan Homogenitas}

Tabel 3. Hasil Uji Normalitas dan Homogenitas Data Nilai SPADI

\begin{tabular}{cccc}
\hline Nilai & \multicolumn{2}{c}{ Shapiro Wilk-Test $\mathrm{p}^{1}$} & \\
\cline { 2 - 3 } SPADI & $\begin{array}{c}\text { Kelompok } \\
\text { I }\end{array}$ & $\begin{array}{c}\text { Kelompok } \\
\text { II }\end{array}$ & $\begin{array}{c}\text { Levene- } \\
\text { Test } \\
\mathrm{p}^{2}\end{array}$ \\
\hline $\begin{array}{c}\text { Sebelum } \\
\text { Perlakuan } \\
\text { Sesudah }\end{array}$ & 0,693 & 0,455 & 0,956 \\
Perlakuan & 0,641 & 0,502 & \\
\hline
\end{tabular}

Data hasil uji normalitas sebelum maupun sesudah perlakuan pada ke dua Kelompok berdistribusi normal $\mathrm{p}>0,05$. Data hasil uji homogenitas data sebelum perlakuan pada ke dua Kelompok bersifat homogen $p>0,05$.

\section{Uji Hipotesis}

\begin{tabular}{cccc} 
Tabel 4. Uji & Hipotesis & \multicolumn{3}{c}{ paired sampel } & t-test \\
\hline \multirow{2}{*}{ Nilai Skor } & Sebelum & Sesudah & \\
SPADI & Perlakuan & Perlakuan & \multirow{2}{*}{$\mathrm{p}$} \\
\cline { 2 - 3 } & Rerata \pm SD & Rerata \pm SD & \\
\hline Kelompok & $74,18 \pm$ & $50,16 \pm$ & 0,00 \\
I & 6,48 & 6,31 & 1 \\
Kelompok & $72,61 \pm$ & $57,86 \pm$ & 0,00 \\
II & 6,83 & 5,32 & 1 \\
\hline
\end{tabular}

Tabel 4. menunjukkan bahwa nilai uji hipotesis Kelompok I dan II didapatkan nilai signifikan $\mathrm{p}<0,05$ yang menyatakan hipotesis 1 dan 2 diterima.

Tabel 5. Uji Hipotesis independent sampel $t$ -

\begin{tabular}{cccc}
\multicolumn{4}{c}{ test } \\
\hline \multirow{2}{*}{$\begin{array}{c}\text { Nilai } \\
\text { Skor }\end{array}$} & Sebelum & Sesudah & Selisih \\
SPADI & Rerakuan & Perlakuan & \\
\cline { 2 - 4 } & Rerata \pm SD & Rerata \pm SD & Rerata \pm SD \\
\hline Kelompo & $74,18 \pm$ & $50,16 \pm$ & $24,01 \pm$ \\
\hline
\end{tabular}

\begin{tabular}{cccc}
\hline k I & 6,48 & 6,31 & 4,41 \\
Kelompo & $72,61 \pm$ & $57,86 \pm$ & $14,75 \pm$ \\
k II & 6,83 & 5,32 & 4,79 \\
\hline Nilai p & 0,625 & 0,013 & 0,001 \\
\hline
\end{tabular}

Berdasarkan Tabel 5. Didapatkan beda rerata nilai SPADI sesudah perlakuan antara Kelompok I dan Kelompok II didapatkan nilai $\mathrm{p}$ sebesar 0,013 atau nilai $\mathrm{p}<0,05$. Berdasarkan hasil uji selisih pada Kelompok I dan Kelompok II juga menunjukkan nilai $\mathrm{p}<$ 0,001 yang artinya nilai tersebut signifikan. Hal ini menyatakan hipotesis 3 diterima.

\section{PEMBAHASAN}

\section{A. Penurunan disabilitas bahu setelah perlakuan kombinasi mobilization with movement dan hold relax exercise serta kombinasi mobilization with movement dan active resistance exercise}

Penelitian sebelumnya mengenai efek MWM pada kasus frozen shoulder idiopatik pada laki-laki dengan usia 57 tahun sudah mengalami keterbatasan ROM, penerapan MWM dilakukan sebanyak $10 x$ repetisi dan dilakukan 2x sehari selama 2 minggu dengan hasil bahwa terjadi peningkatan ROM pada gerakan eksternal rotasi, abduksi dan fleksi disertai juga dengan penurunan rasa nyeri yang dirasakan ${ }^{10}$. Selain itu penelitian yang membandingkan teknik end range mobilization (ERM) dan MWM pada kasus frozen shoulder, menunjukan hasil subjek mengalami perubahan selama 12 minggu, tetapi perubahan signifikan dalam penelitian ini sudah terlihat setelah 3 minggu perlakuan. Secara statistik terlihat pada Kelompok ERM dan Kelompok MWM, selain itu perbaikan scapulohumeral rhythm dengan MWM lebih baik dibanding ERM. Sesuai dengan penelitian yang dilakukan ini MWM diberikan selama 6 minggu berguna untuk memperbaiki perubahan postur pada scapulohumeral joint dan meningkatkan ROM pada sendi bahu ${ }^{8,11}$. Hasil dalam penelitian lainnya yang menggunakan sampel dengan rentang usia 40-60 tahun mendapatkan hasil bahwa grup perlakuan "B" yang menerapkan teknik MWM untuk mengurangi nyeri dan 
menurunkan disabilitas pada kasus frozen shoulder mengalami penurunan nilai SPADI dari nilai pre test rata-rata 72,77 dan setelah perlakuan selama $2 x$ dalam seminggu selama 3 minggu perlakuan mendapatkan nilai ratarata post test $44,07^{12}$. Jika dibandingkan pada penelitian sebelumnya, pemberian teknik MWM diterapkan dalam 3 minggu sudah menunjukkan perubahan yang signifikan sedangkan pada penelitian ini melakukan penelitian selama 6 minggu pertemuan dan juga terjadi perubahan yang signifikan. Selain itu penelitian lainnya juga membuktikan keunggulan MWM dibandingkan teknik manual lainnya ${ }^{11,13}$. Penelitian lainnya menunjukan bahwa kekuatan mekanik selama pemberian $M W M$ memungkinkan melepaskan perlengketan adhesive, mengembalikan fungsi collagen dan meningkatkan fiber glide ketika terjadi tekanan pada gerakan tertentu yang menginisiasi bagian dari kapsul sendi. Sehingga selanjutnya mobilization akan meningkatkan atau mempertahankan mobilitas sendi dengan menginduksi perubahan biologis pada cairan synovial, sehingga terjadi peningkatan. Teknik MWM akan meregangkan jaringan lunak yang mengalami tightness dan mengembalikan ukuran panjang normal pada kapsul sendi bahu dan menormalkan scapulohumeral rhytm dan memberikan efek yang baik ${ }^{14}$.

Sedangkan tambahan kombinasi pada perlakuan I yaitu teknik hold relax exercise yang merupakan bagian dari teknik PNF. Dalam sebuah studi disarankan bahwa terapi peregangan menggunakan PNF efektif untuk meningkatkan LGS. Teknik ini akan menekankan pada terjadinya peregangan pada otot. HRE adalah teknik isometrik yang efektif ketika rasa sakit menyertai pembatasan gerakan atau merupakan penyebab utama dari immobilitas $^{7}$. Penelitian sebelumnya mengenai HRE mendapatkan hasil bahwa teknik dengan HRE dapat meningkatkan LGS bahu pada frozen shoulder ${ }^{15}$. Hasil yang selaras juga ditunjukan pada penelitian lainnya yaitu terjadi penambahan jarak gerak abduksi sendi bahu sesudah diberikan teknik hold relax exercise pada frozen shoulder, penelitian ini dilakukan selama 4 bulan dengan rentang usia sampel 45-50 tahun, ratarata peningkatan gerakan abduksi bahu dari pemeriksaan awal $143,70^{\circ}$ menjadi $154,50^{\circ 16}$. Selain itu penelitian di Turki pada 36 orang sampel dengan $5 x$ pertemuan setiap minggu selama 15 minggu mendapatkan hasil bahwa pemberian teknik PNF berupa hold relax exercise lebih meningkatkan ROM sendi bahu pada gerakan fleksi dan abduksi dibandingkan dengan pemberian terapi konvensional dengan nilai skor SPADI pada Kelompok I (PNF) sebelum terapi 79,44 menjadi 34,69 sedangkan pada Kelompok II (konvensional terapi) sebelum terapi skor SPADI 63,98 menjadi $41,71^{17}$. Hasil yang diperoleh dari penelitian ini sejalan dengan studi sebelumnya yang melakukan penelitian dengan teknik PNF yaitu teknik hold relax exercise dilakukan $4 \mathrm{x}$ dalam seminggu selama 4 minggu berturut-turut dan menemukan bahwa terdapat penurunan yang signifikan pada indeks disabilitas bahu ketika dilakukan teknik hold relax exercise secara rutin karena menyebabkan terjadinya perangsangan melalui kontraksi maksimal dari Kelompok otot yang tegang sehingga diharapkan terjadi kontraksi sejumlah motor unit secara maksimum dan bersamaan ${ }^{18}$.

Sedangkan tambahan kombinasi yang diterapkan pada Kelompok II yaitu active resistance exercise ditekankan pada peningkatan kekuatan otot yang bertujuan meningkatkan lingkup gerak sendi bahu. Sesuai dengan apa yang didapat pada penelitian ini (Tabel 4) bahwa adanya penurunan nilai SPADI setelah perlakuan selama 6 minggu hal ini selaras dengan temuan pada penelitian terdahulu yang melakukan penelitian selama 6 minggu sebanyak 6x pertemuan dengan menerapkan teknik active resistance exercise mendapatkan hasil terjadinya penurunan nyeri, peningkatan LGS, peningkatan kekuatan otot dan penurunan nilai disabilitas pada bahu yang diukur dengan SPADI ${ }^{19}$. Selain itu penelitian mengenai efek dari resistance exercise menggunakan elastic band untuk meningkatkan range of motion (ROM), perlakuan ini diberikan pada 42 subjek dibagi menjadi 2 Kelompok perlakuan dan 
Kelompok kontrol, perlakuan dilakukan selama 4 minggu, mendapatkan hasil signifikan dan terjadi peningkatan ROM dan meningkatnya fungsional pada $\mathrm{bahu}^{20}$. Hal tersebut sejalan dengan apa yang peneliti temukan bahwa active resitance exercise menggunakan resistance band dapat meningkatkan kekuatan otot, mengembalikan fungsional bahu dan menurunkan disabilitas pada bahu. Penelitian penunjang lainnya juga mendapatkan hasil bahwa pemberian active resistance exercise dapat meningkatkan kekuatan otot dan menurunkan keterbatasan LGS pada bahu setelah diberikan perlakuan sebanyak 6x selama 3 minggu $^{21}$.

Sejalan dengan penelitian sebelumnya setelah pemberian active resistance exercise selama 6x pertemuan juga terjadi penurunan nyeri, peningkatan kekuatan otot, peningkatan LGS bahu serta peningkatan kemampuan fungsional pada kasus frozen shoulder ${ }^{22,23}$. Penerapan latihan seperti active resistance exercise pada fase stiff phase sangat berguna untuk mempertahankan kekuatan otot ${ }^{24}$. Sejalan dengan penelitian terdahulu mengenai active resistance exercise terhadap 24 orang perempuan mendapatkan hasil bahwa terjadi penurunan nyeri pada ke dua perlakuan setelah diukur menggunakan Visual Analouge Scale (VAS). Sedangkan pada range of movement (ROM) dan shoulder functional indeks (SFI) didapatkan hasil teknik resistance exercise (eksperimental grup) lebih efektif dibandingkan dengan grup kontrol ${ }^{25}$.

Pergerakan aktif dalam meningkatkan LGS ini terjadi karena adanya rangsangan proprioseptif dengan perubahan panjang otot pada saat terjadi kontraksi otot, darah bergerak ke jaringan sehingga pada sendi terjadi penambahan nutrisi, kemudian memungkinkan terjadinya penurunan perlengketan jaringan, dengan demikian LGS dapat bertambah ${ }^{26}$.

B. Mobilization With Movement dan Hold Relax Exercise Lebih Menurunkan Disabilitas Pada Kasus Frozen shoulder Idiopatik Dari Pada Mobilization With Movement dan Active Resistance Exercise
Berdasarkan hasil uji data dalam penelitian ini didapatkan kombinasi MWM dan HRE lebih menurunkan dibandingkan MWM dan ARE. Pada Kelompok I diberikan tambahan HRE disana terjadi proses kontraksi otot secara isometrik dan terjadi pula peregangan pada otot tersebut. Hal tersebut terjadi oleh karena saat kontraksi isometrik terjadi dan diberikan tahanan dari luar maka kekuatan isometrik semakin bertambah sehingga menyebabkan penambahan regangan pada tendon, oleh karena itu GTO mendapat rangsangan yang lebih sehingga menyebabkan rangsangan pada GTO mencapai ambang rangsangnya. Makin kuat otot diregang, maka makin kuat pula kontraksinya. Bila tegangan otot menjadi lebih besar, kemudian kontraksi tadi mendadak dihentikan dan otot melemas, maka terjadilah proses relaksasi otot (autogenic inhibition reflex). Sehingga dapat menyebabkan regangan yang lebih jauh dari otot yang semula melakukan kontraksi isometrik sehingga dapat melampaui titik kelentukan yang maksimum (batas nyeri) ${ }^{26}$.

Hal inilah yang menyebabkan pada metode hold relax exercises memungkinkan pemanjangan otot bisa lebih optimal dibandingkan dengan metode peregangan lainnya. Sedangkan pada Kelompok II diberikan tambahan ARE, terjadi peningkatan aliran darah ke otot yang aktif oleh karena kebutuhan oksigen yang meningkat, trasportasi nutrisi ke otot meningkat, peningkatan jumlah protein dalam serabut otot dan kenaikan jumlah motor unit. Terjadinya peningkatan rekruitment motor unit sehingga akan semakin banyak melibatkan komponen otot yang bekerja. Maka kontraksi otot secara keseluruhan tergantung dari jumlah motor unit yang mengaktifkan otot pada saat itu ${ }^{27}$. Jumlah motor unit yang besar akan menimbulkan kontraksi otot yang kuat tetapi tidak terjadinya peregangan pada otot tersebut, beda halnya pada perlakuan HRE yang selain meningkatkan kekuatan otot juga dapat memberikan efek peregangan maksimal pada otot-otot yang dituju. 
Dapat disimpulkan bahwa kombinasi mobilization with movement dan hold relax exercise lebih menurunkan disabilitas pada kasus frozen shoulder idiopatik dari pada kombinasi mobilization with movement dan active resistance exercise.

\section{SIMPULAN}

1. Kombinasi mobilization with movement dan hold relax exercise menurunkan disabilitas bahu pada kasus frozen shoulder idiopatik.

2. Kombinasi mobilization with movement dan active resistance exercise menurunkan disabilitas bahu pada kasus frozen shoulder idiopatik.

3. Kombinasi mobilization with movement dan hold relax exercise lebih baik daripada kombinasi mobilization with movement dan active resistance exercise dalam menurunkan disabilitas bahu pada kasus frozen shoulder idiopatik.

\section{SARAN}

1. Perlakuan kombinasi mobilization with movement dan hold relax exercise sebaiknya diteruskan dan diterapkan sebagai dasar pelayanan fisioterapi di klinik dengan tujuan menurunkan disabilitas pada bahu pada pasien yang masuk ke dalam kategori phase II (stiff phase) pada kasus frozen shoulder idiopatik.

2. Untuk peneliti selanjutnya diharapkan waktu penelitian diperpanjang untuk lebih meyakinkan kembali pengaruh intervensi yang diberikan.

3. Agar diawasi postur saat melakukan aktivitas atau pada saat bekerja.

4. Agar diawasi durasi melakukan suatu aktivitas fisik atau pekerjaan yang dilakukan di luar jam penelitian.

\section{DAFTAR PUSTAKA}

1. Magee, D. J. 2013. Orthopedic Physical Assessment. fifth edition. Sounders Elsevier: Philadelphia.
2. American Academy of Orthopaedic Surgeons, 2018. Frozen shoulder. Diakses tanggal 24/09/2019, dari http://orthoinfo. aaos.org/topic.cfm?topic $=$ A00071\&return link $=0$

3. Varcin, L. 2013. Unlocking Frozen Shoulder New Paradigm of Treatment. Balboa

4. Kelley, Martin J., Michael A. Shaffer., John E. Kuhn., Lori A. Michener., Amee L. Seitz., Timothy L. Uhl., Joseph J. Godges., Philip W. Mcclure. 2013. Shoulder Pain and Mobility Deficits: Adhesive Capsulitis. Journal Orthopedi Sports Physical Therapy 2013;43(5) : A1A31. Doi :10.2519/jospt.2013.0302

5. Morgan, W.E and Potthoff, S. 2012. Managing the Frozen shoulder: Self-care manual for those suffering from frozen shoulder e-book, diakses tanggal 25/01/2015, Available from http://drmorgan.info/data/documents/froze n -shoulder-ebook.pdf

6. Rangan, A. 2015. Frozen Shoulder, Shoulder and Elbow, 7 (4), pages 299-307

7. Suprawesta, L. 2015. Pelatihan Hold relax Dan Terapi Manipulasi Lebih Menurunkan disabilitas bahu Daripada Pelatihan Contract Relax Dan Terapi Manipulasi Pada Penderita Frozen shoulder. Sport and Fitness Journal : Volume 4 Nomor 1, Maret 2017 (ISSN : 2355 - 4355)

8. Putri, A.R., dan Wulandari. I.D. 2018. Penatalaksanaan Fisioterapi Kondisi Frozen shoulder E.C Tendinitis Muscle Rotator Cuff Dengan Modalitas Short Wave Diathermy, Active Resistance Exercise Dan Codman Pendular Exercise. Jurnal PENA Voume 32 Nomor 2 Edisi September 2018

9. Yang, J., Chang, C., Chen, S., Wang, S.F., and Lin, J. 2007. Journal of the American Physical Therapy Assosiation. 87 (10) : 1309

10. Mhaske, G., Kala, N., Patil, P. 2017. Immediate effect of mulligan's mobilization with movement in frozen shoulder : A case report. MedPulse International Journal of Physiotherapy, 
Print ISSN : 2579-1133, Volume 1, Issue

2, February 2017, Pages : 22-24

11. Trisnowiyanto, B. 2016. Beda Pengaruh Intervensi Peregangan Dan Mobilisasi Sendi Terhadap Perbaikan Keterbatasan Lingkup Gerak Sendi. Jurnal Kesehatan, Volume VII, Nomor 2, Agustus 2016, hlm 182-188

12. Goyal, M. 2013. Combined Effect of End Range mobilization (ERM) and Mobilization with Movement (MWM) Techniques on Range Of Motion and Disability in Frozen shoulder Patients: A Randomized Clinical Trial; Journal of Exercise Science and Physiotherapy. Journal of Exercise and Phsiotherapy. Vol. 9 No. 2, 74-82.

13. Patel, S., Nagrale,S., Dabadghav, R., Bedekar, N., and Shyam, A. 2016. The effect of mulligan mobilization with movement technique on internal rotation range of motion of glenohumeral joint in patient with adhesive capsulites. Indian Journal Physitheraphy Volume : 3, Number : 2, Pages : 71

14. Teys, P., Bisset, L., and Vicenzino, B. 2006. The Initial Efect of a Mulligan's Mobilization with Movement Technique on Range of Movement and Pressure Pain Threshold in Pani-limited Shoulder. Manual Therapy. 13 (4) : 37-42

15. Astuti, D.N. 2018. Perbedaan Pengaruh TENS dan Terapi Manipulasi Dengan TENS dan Hold Relax Terhadap LGS Bahu Pada Pasien Frozen shoulder. Jurnal Fisioterapi dan Rehabilitasi, Volume 2, Nomor 2, ISSN 2548-8716

16. Suharto, Suriani, dan Leksonowati, S.S. 2016. Pengaruh Teknik Hold relax terhadap Penambahan Jarak Gerak Abduksi Sendi Bahu pada Frozen shoulder di Ratulangi Medical Centre Makassar. Buletin Penelitian Kesehatan, Vol. 44, No. 2, Juni 2016:103-108

17. Eda, A., Sinem, G., Emin, U.E., Inci, Y. 2015. The Effect of Additional Proprioceptive Neuromuscular Facilitation Over Conventional Therapy In Patients With Adhesive Capsulitis.
Turkish Journal of Physiotherapy and Rehabilitation $2015: 25$ (2)

18. Kondatrek, M.P.M.E., Krauss, J., Preston, D. 2012. Effects of Hold Relax and Active Range of Motion on Thoracic Stability. Journal International Academy Physiotheraphy Res. 2012;3 (2) : 413 - 78

19. Jannah, A.H.N. 2017. Penatalaksanaan Trancutaneus Electrical Nerve Stimulation (TENS), Terapi Manipulasi dan Terapi Latihan pada Frozen shoulder Sinistra.

20. Sim, J. 2016. Effect Of Resistance Exercise Using Elastic Band On Range Of Motion Function And Shoulder Pain Among Patients With Rotator Cuff Repair. Korean Jurnal of Adult Nursing Volume 28, Issue (5), hlm 491-500

21. Sa'Diah, M. 2019. Penatalaksanaan Fisioterapi Pada Keterbatasan Lingkup Gerak Sendi Bahu Akibat Post Orif Fraktur Shaft Humerus Dextra di Kelurahan Alalak Utara Banjarmasin Tahun 2018. Jurnal Kajian Ilmiah dan Teknologi Volume 1 Nomor 1 ISSN 26567733

22. Kurniasari, S.N. 2010. Penatalaksanaan terapi latihan pada kondisi paska operasi pertrokanter femur dekstra dengan pemasangan plate and screw. Jurnal Pena 19 (1), Hlm 48 - 57

23. Romadhoni, D.L. 2015. Penatalaksaan Fisioterapi Pada Kasus Frozen shoulder Akibat Capsulitis Adhesiva Sinistra di RSUD Dr. Moewardi Surakarta

24. Chan, H.B.Y. , Pua, P.Y., and How, C.H. 2017. Physical Therapy In Management Of Frozen shoulder. Journal Singapore Medical Volume 58, Issue (12), hlm 685689

25. Nam, K.W. and Ha, M.S. 2012. Effect of Self Resistance Exercise in Women with Frozen shoulder. Journal Korea of Physioteraphy Science Vol: 19-02-2012 (30) Pages : 35-42

26. Wahyono, Y., dan Utomo, B. 2016. Efek Pemberian Latihan Hold Relax dan Penguluran Pasif Otot Quadriceps Terhadap Peningkatan Lingkup Gerak Fleksi Sendi Lutut dan Penurunan Nyeri 
Pada Pasien Pasca ORIF karena Fraktur Femur 1/3 Bawah dan Tibia 1/3 Atas. Jurnal Terpadu Ilmu Kesehatan, Volume 5, No 1 Mei 2016, hlm $01-109$

27. Kisner, C., Colby, L. A. 2012. Therapeutic Exercise Foundation and Technique. Sixth Edition, F. A. Davis Company, Philadelphia. 